ELORE (ISSN 1456-3010), vol. 17 - 2/2010.

Julkaisija: Suomen Kansantietouden Tutkijain Seura ry.

[http://www.elore.fi/arkisto/2_10/ingemark_2_10.pdf]

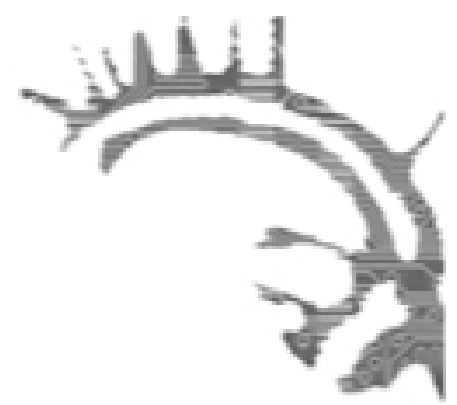

\title{
EN UPPTECKNARE BERÄTTAR - BERÄTTARTEKNIK I JAKOB EDVARD WEFVARS UPPTECKNINGAR OM SLAGET VID ORAVAIS I 808
}

\author{
Camilla Asplund Ingemark
}

\begin{abstract}
En del af Svenskarne vid återtåget blefvo vid sjöstranden kringrände af Ryssarne. I denna trupp befunno sig äfven àtskilliga svenska bönder. Soldaterne angrepo nu Ryssarne och slogo sig igenom. "Huru gick det med eder, när i måsten laga er undan Ryssarne?" frågade folket af dem, när de sedan om aftonen kommo hem. "Visst hörde vi gevären skramla", svarade de, när den trupp, der desse bönder voro, slog sig igenom sina fiender och banade med bajonetten sig väg fram till landsvägen.”
\end{abstract}

När vi idag inom den folkloristiska forskningen bedömer användbarheten av äldre arkivmaterial utifrån dagens tekniska, metodologiska och teoretiska måttstockar, är det ofta med ett visst beklagande vi närmar oss den typ av uppteckningar jag diskuterar här (se till exempel Bergman 1981, 31-32). Jakob Edvard Wefvars uppteckningar om slaget vid Oravais den 14 september 1808 utgör nämligen ett kompilat av berättelser som han hört från olika håll och sedan vävt samman till en större berättelse. Denna berättelse ingår i Svenska litteratursällskapets i Finland samlingar såsom SLS 102, men en motsvarighet finns också i en annan Wefvarsamling, SLS 275.

Kompilatets dåliga rykte beror kanske dels på den vetenskapligt grundade åsikten att sammanblandningen av olika berättares berättelser till en helhet omintetgör möjligheten att rekonstruera vem som har berättat vad, hur och varför, dels på den mer känslomässigt betonade tanken att det fördärvar uppteckningarnas autenticitet som vittnesbörd om en levande folklore. I föreliggande artikel vill jag vända på denna problematik och istället fokusera på kompilatet som ett utslag av upptecknarens berättande. Jag frågar mig enligt vilka principer Wefvar fogade samman berättelserna, det vill säga hurdan hans disposition var, och hur den påverkade kronologin i den berättelse han skapade. Jag granskar också i vilken mån han lät andra berättare komma till tals, det vill säga i vilken grad han "tog över" sagesmännens berättelser och så att säga framställde dem som sina egna. I undersökningen av dessa problemställnin- 
Camilla Asplund Ingemark: En upptecknare berättar

gar använder jag mig av ett antal begrepp hämtade från textanalys och narratologi: disposition, kronologisk ordning och berättarröst. Innan jag diskuterar dessa begrepp, presenterar jag dock materialet och dess insamlare.

\section{JAKOB EDVARD WeFVARS SAMLINGAR AV HISTORISKA SÄGNER}

Det analyserade materialet ingår i de relativt omfattande samlingarna av historiska sägner om 1808-09 års krig - beräknade att uppgå till cirka 900 - som finns i Svenska litteratursällskapets i Finland Folkkultursarkiv. Bland dessa intar Jakob Edvard Wefvars uppteckningar en särställning tack vare sitt omfång och rika innehåll, tillsammans med en dryg handfull samlingar av V.E.V. Wessman. SLS 102, liksom SLS 275 , består av sägner insamlade på 1860- och 1870-talet i hela det svenskspråkiga området i Finland, men berättelserna om slaget vid Oravais är upptecknade bland lokalbefolkningen på orten eller i grannsocknen Vörå, där den svenska och ryska hären också rörde sig i samband med drabbningen. I SLS 102 omfattar berättelsen 10 handskrivna sidor, medan motsvarande material i SLS 275 uppgår till 23 sidor. Av utrymmesskäl begränsar jag mig följaktligen till att analysera uppteckningarna i den förstnämnda samlingen, med vissa jämförelser med den senare för att fă med kompletterande information. Uppteckningarna i SLS 275 bildar inte heller en lika sammanhållen helhet som i SLS 102, där de verkligen kan sägas utgöra en enda större berättelse.

Jakob Edvard Wefvar, torparson från Linnusperä by i Gamlakarleby socken, inledde sin bana som insamlare av folklore under sin skoltid, då han på uppdrag av J.O.I. Rancken, rektor för Vasa lyceum, tecknade ner folktraditioner mot en mindre ersättning. Resultatet av hans ansträngningar bildar lejonparten av den så kallade Ranckensamlingen, som numera uppbevaras vid Folkloristiska arkivet vid Åbo Akademi. Han fortfor att för olika uppdragsgivare, däribland Svenska litteratursällskapet, verka som upptecknare av folklore under hela sitt liv (Andersson 1967, 123; Wolf-Knuts 1991, 20-24).

När jag arbetade på en utgåva av historiska sägner om 1808-09 års krig i samband med 200-årsjubileet, kom jag också i kontakt med Wefvars uppteckningar (Asplund Ingemark \& Wassholm 2009). De gjorde mig mycket förvånad. Den Wefvar jag var van vid från Ranckensamlingen, som jag gick igenom vid arbetet på min doktorsavhandling (Asplund Ingemark 2004), skrev nämligen ner nästan all folklore på dialekt, men här fanns många uppteckningar på högsvenska. Vissa av dem var också kompilat. Jag fäste mig särskilt vid uppteckningarna om slaget vid Oravais, som verkade mer sammanhängande och helgjutna är de andra. Till slut insåg jag att de utgjorde en berättelse, och började intressera mig för hur denna var uppbyggd och varför den skrivits. 
Camilla Asplund Ingemark: En upptecknare berättar

\section{DISPOSITION, KRONOLOGISK ORDNING OCH BERÄTTARRÖST}

En disposition utgör ett logiskt mönster för hur man fogar samman de olika delarna av en text. Beroende på vilken konkret princip som länkar en del av texten till en annan, kan man tala om olika dispositionstyper. Några vanligt förekommande typer är tidsdispositionen, där den temporala relationen mellan delarna bildar kittet; rumsdispositionen, där en förflyttning i rummet utgör förbindelsen; orsaksdispositionen, där orsak och verkan står i fokus samt temadispositionen, där ett fenomen betraktas ur olika synvinklar och bestämmer textens rörelse. Temadispositionen kan exempelvis vara additiv, om den bygger på sidoordning utan större fördjupning (Hellspong \& Ledin 2006, 98-100). När det handlar om berättelser som länkas samman, såsom här, kan det tilläggas att det mönster som vi tycker oss skönja skapas genom att vi läser bakåt, det vill säga, vi läser in ett mönster i helheten när vi sett vilka aspekter av de tidigare berättelserna som återkommer i de senare (Young 1987, 81-82).

Det kan naturligtvis förekomma ett antal dispositionstyper i samma text: dels kan de avlösa varandra, dels kan de finnas på olika nivåer (Hellspong \& Ledin 2006, 100). På en övergripande nivå är till exempel dispositionen i Wefvars berättelse om slaget vid Oravais en tidsdisposition, eftersom den bygger på drabbningens förlopp, men vid sammanfogningen av berättelsens delar har han också använt sig av andra dispositionstyper. Valet av dispositionstyp påverkar sedan tidens lopp i berättelsen. Återigen är en rak kronologi dominerande på en övergripande nivå: berättelsen rör sig i det stora hela från arla morgonstund till kvällen, men i skarvarna mellan berättelsens beståndsdelar rör den sig både bakåt och framåt i tiden. Det förekommer alltså både tillbakablickar (singularis analeps, av grekiskans "ta bakåt") och framåtblickar (singularis proleps, av "ta i förväg") i förhållande till ramberättelsens tid (Genette 1983, 40). Berättelsen kan sålunda sägas utspela sig på olika tidsplan samtidigt, på en mikro- respektive makronivå. Den komplexa kronologi som sålunda uppstår antyder hur Wefvar har tolkat slaget som en historisk händelse, eftersom dispositionstypen kan visa vilka aspekter av det historiska skeendet han uppfattade som viktiga.

Berättarrösten är den som för ordet i berättelsen, och berättarrösten byggs upp av olika element, varav berättelsenivå och person är intressanta här. Berättandet i en berättelse kan ju äga rum på olika nivåer, beroende på hur berättarrösten placerar sig i förhållande till berättelsens värld. På den högsta nivån återfinns den utomstående berättaren som skildrar en värld han eller hon själv inte lever i (den extradiegetiska nivån, det vill säga utanför berättelsen). På en lägre nivå sker berättandet av en berättare som skildrar sin egen värld (den diegetiska eller intradiegetiska nivån). På den tredje nivån (den metadiegetiska) framför berättaren en berättelse inuti ramberättelsen, och är ofta en karaktär i denna (Genette 1983, 228-229).

Angående person, kan berättarrösten berätta om andra, och är då en heterodiegetisk berättare, eller själv vara med som en karaktär i berättelsen, varvid den är en homodiegetisk berättare. Om den därtill är huvudperson och framförallt berättar om sig själv, är den också autodiegetisk. Berättelsenivå och person kan sedan kombineras 
med varandra, så att såväl den som berättar som dem det berättas om tas i betraktande samtidigt (Genette 1983, 244-245, 248). Wefvars berättelse om slaget vid Oravais uppvisar berättande på flera olika nivåer i denna mening, och har även en urskiljbar primär berättare, som inte kan identifieras med någon av hans sagesmän eller med Wefvar själv. Hans berättarteknik får nämligen konsekvenser som ibland torde vara både oavsiktliga och oförutsedda.

Förutom dessa analytiska begrepp använder jag mig även av ett antal termer för att benämna de olika delarna av den studerade berättelsen. Berättelsen som helhet kallar jag ramberättelse, medan de enskilda berättelser den består av - vilka numreras i citaten - har fått benämningen delberättelser. När så behövs har jag lånat två termer från William Labovs modell för analys av berättelsemönster, nämligen bakgrundsorientering (orientation) och värdering (evaluation). I bakgrundsorienteringen presenteras tiden och scenen för berättelsen, karaktärerna och deras situation, och i värderingen formuleras berättelsens poäng och betydelse (Labov 1972, 364, 366). Termen berättare används för att beteckna berättarinstansen i berättelsen och det äldre sagesman för Wefvars källor, för att skilja dem åt analytiskt.

För att kunna orientera sig i berättelsen är det dock nödvändigt att ha viss inblick i hur slaget vid Oravais förlöpte, så i det följande skisseras den historiska bakgrunden. Därefter citeras och analyseras berättelsen i lämpliga avsnitt.

\section{808-09 ÅRS KRIG OCH SLAGET VID ORAVAIS}

Finska kriget 1808-09 hade sin bakgrund i de så kallade Napoleonkrigen 1803-1815 och Napoleons kontinentalblockad mot Storbritannien. Sverige ingick i en koalition mot Frankrike tillsammans med Storbritannien, Österrike, Preussen och Ryssland, men då de andra medlemmarna vartefter besegrades av Napoleon, blev Sverige till slut ensamt kvar vid britternas sida. Ryssland och Frankrike slöt år 1807 det så kallade avtalet i Tilsit, där tsar Alexander I lovade att med alla tillgängliga medel förmå Sverige att ansluta sig till kontinentalblockaden. Eftersom Sveriges kung, Gustav IV Adolf, hyste stora antipatier mot Napoleon, vägrade han att underordna sig dennes vilja. Alexander I såg sig då tvungen att anfalla Sverige, vilket han gjorde i februari 1808 utan föregående krigsförklaring. Kriget pågick tills freden slöts i Fredrikshamn i september 1809. Finland blev ett ryskt storfurstendöme (Hårdstedt 2006, 11-12, 19, 24-25, 286-289, 336).

Slaget vid Oravais den 14 september 1808 inföll vid en tidpunkt då kriget redan hade vänt till svenskarnas nackdel, och ingick i en reträtt norrut som skulle sluta först på den sedermera svenska sidan av Torne älv. Striderna inleddes klockan 5 på morgonen, då den svenska förposten förlagd vid det så kallade Lillträsket attackerades av den ryska förtruppen under befäl av Jakov Petrovitj Kulnev. Lillträsket ligger väster om Fjärdsbacken, där svenskarnas huvudställning var, och Fjärdsån, som delar fältet nedanför backen. Träsket mynnar ut i Oravaisfärden, och landsvägen till Vörå och Vasa går över det via en bro, som numera kallas "Schwerins bro" efter Wilhelm 
von Schwerin. Förpoststriden förlöpte i upprepade anfall och motanfall på vägen och i skogen bredvid vägen, men ryssarna fick sedan ett övertag då en ny trupp under Nikolaj Ivanovitj Demidov anlände. Denne påbörjade en kringgångsmanöver i skogen söder om vägen. Kring klockan 10 beslöt svenskarna att retirera till huvudställningen vid Fjärdsbacken (Hårdstedt 2006, 162-165).

Under Carl Johan Adlercreutz' befäl ställde svenskarna nu upp sig på slaglinje utefter Fjärdsbacken i nord-sydlig riktning, och ryssarna gjorde likadant på andra sidan Fjärdsån. Därpå följde en timslång artilleriduell, varefter en ny våg av anfall och motanfall började. Först försökte ryssarna anfalla svenskarnas högra flygel som stod mot Oravaisfärden till, men då detta misslyckades förlades tyngdpunkten i anfallet till den vänstra istället, som var mindre skyddad. Striden trappades upp klockan ett, då de ryska anfallen blev hårdare, men den svenska linjen höll. Nu påbörjade de svenska trupper som stod närmast den ryska linjen ett spontant motanfall, så att de lämnade sina positioner och vadade över Fjärdsån, där ryssarna mötte dem med häftig eldgivning. Inför detta hot inledde de en mestadels oordnad reträtt, som kunde ha slutat med att den svenska linjen upplöstes, om inte en annan svensk trupp hade marscherat fram och skyddat reträtten med muskötsalvor (Hårdstedt 2006, 166-168).

En timme senare, klockan två, beslutade Adlercreutz att genomföra ett anfall längs landsvägen, där den ryska linjen hade tunnats ut. Den ryska eldgivningen medförde stora förluster, men trots detta samt svårigheten att ta sig över Fjärdsån vilket ledde till ett okoordinerat bajonettanfall, lyckades de svenska trupperna få ryssarna att vika. Dessa jagades ända till platsen för förpoststriden på morgonen. Nu kom dock den ryska reserven under Nikolaj Michailovskij Kamenskij fram till slagfältet, och svenskarna tvangs retirera till Fjärdsbacken. Deras ammunition började ta slut och soldaterna var trötta. En del av dem blev efter, drevs ut på en udde och måste slå sig igenom, medan andra simmade över vattnet. Svenskarna bildade en ny linje, som låg närmare Oravais by och som var vänd österut mot Kimovägen. Det var nu skymning, och ryssarna förnyade sina anfall. De svenska trupperna hade fått mer ammunition, men inte tillräckligt. När ryssarna satte in slutanfallet klockan tio på kvällen var ammunitionen åter slut, och Adlercreutz beordrade reträtt. På morgonen den 15 september kom den svenska armén till Nykarleby (Hårdstedt 2006, 168-173).

\title{
BERÄTTELSEN
}

\author{
Enskilda berättelser om tilldragelser och händelser ifrän slaget vid Oravais den 14 Septem- \\ ber 1808. Dessa berättelser äro upptecknade såsom de muntligen för mig blifvit skildrade af \\ personer, hvilka lefde samma tid eller så lång tid efteråt, att de ihågkomma hvad de sjelfve \\ upplefvat, eller deras fäder för dem berättat. [1] År 1878 lefde ännu en 80års gammal \\ man, som var son till en dalkarl, som samma tid var arrendator àt prosten Vegelius, då \\ kriget utbröt $i$ landet. Redan ett par dagar före fältslaget $i$ nämnde Oravais skog, började \\ Kosacker visa sig. De togo efter hästar, der de kunde àtkomma sädana. Af prostens hästar \\ voro åtminstone ett par $i$ hagen. Arrendatorns gosse, som då var 10 àr II fotnot: "Samma
}


Camilla Asplund Ingemark: En upptecknare berättar

\begin{abstract}
gosse, som var 1876 omkring 78 år gammal samt frisk kunde då ge upplysningar om ett och annat frän Oravais slaget[?]".] gammal jämte en annan jämnårig gosse skulle visa Kosackerne, hvar prostens hästar funnos. De gjorde det. Men desse voro ej heller skygge eller ängslige af sig, utan när Kosackerne skulle taga fast hästarne, slogo de med störarne till dem att de blefvo rädda och sprungo mellan Kosackernes hästar till skogen. Häröfver blefvo desse förargade och ämnade ränna piken i dem; men gossarne slogo då med störarne till Kosackernes pikar, att de föllo dem ur händerna till marken samt skyndade àt skogen och gömde sig bland träden. En stund voro Kosackerne borta till prestgården, så kommo de tillbaka till hagen och började gå och söka efter pojkarne. Möjligen hade de ock kunnat träffa dem, ty de stodo bakom en stor sten, hvarifrän de kunde se sina fiender, men ett töcken slog öfver fältet samma gång att Kosackerne intet varseblefvo dem utan drogo tillbaka samma väg som de kommit. Sedan de hade aflägsnat sig gingo äfven gossarne hem. De hade således, desse gossar, mäktat bevara gårdens hästar för Kosackerne och äfven visat sina fiender, att de icke "skyggade för hvad som röres i busken". [2] Dagen före berörda slag kom fältmarskalk Klingspor ridande på en appelgrå häst till prestgården. På min fråga hvad fältmarskalk Klingspor hade för ärende till prostgården? svarade samme man, som 1876 var 78 gammal och som 11 àrs gosse sett Klingspor: "fy ti fuà se nainting i munn." [för att få sig någonting i mun.] "Huru länge var han der?" frägade jag vidare. "Säkert 2 timmar," svarade han. Det var middagstiden, när han kom.
\end{abstract}

(SLS 102, 272-273)

Wefvar inleder sin berättelse med att uppge sina källor, det vill säga personer som berättat om egna upplevelser, eller hört sina då levande släktingar omtala det som hänt. Därmed skänker han sitt eget berättande ett särskilt berättigande, eftersom det bygger på trovärdiga källor (jfr Siikala 1990, 96). Här etablerar sig också den primäre berättaren som sådan genom sin hänvisning till det egna subjektet. Det är denne berättare som sedan för ordet i nästa mening, ”År 1878 lefde ännu en 80års gammal man...". Denna information har förmodligen inte ingått i själva berättelsen då den förmedlades av sagesmannen, men har här dragits in i den som ett bakgrundsorienterande parti. Den primäre berättaren är här extradiegetisk och heterodiegetisk, det vill säga han tillhör inte själv berättelsens värld, utan berättar om andra.

Därefter följer ett längre bakgrundsorienterande avsnitt som är tätare knutet till själva händelsen i den första delberättelsen, och som därför kan ha sitt upphov hos sagesmannen. Eftersom denne omtalas i tredje person, fastän det uppenbarligen rör sig om en personlig erfarenhetsberättelse, är det likväl inte denne som är berättare. Den primäre berättaren har fortfarande ordet, och har tydligen omvandlat vad som ursprungligen var en intradiegetisk-autodiegetisk berättelse till en extradiegetisk-heterodiegetisk sådan. Berättelsenivån har således ändrats från en inomvärldslig till en utomvärldslig, och personen från en som beskriver det självupplevda till en som ger en redogörelse för andras erfarenheter. Den primäre berättaren har tagit kontroll över sagesmannens berättelse, och denne får inte längre själv berätta sin egen historia. Delberättelsen avslutas med den primäre berättarens värdering, att gossarna varit modiga då de kunnat bevara prostgårdens hästar för kosackerna.

Nästa delberättelse har länkats till den första genom en temadisposition, då det är 
prostgården och dess folk som utgör den gemensamma nämnaren. Här lämnar den primäre berättaren sin extradiegetiska position och tar plats i berättelsen som en intradiegetisk berättare, varvid han inleder ett samtal med sagesmannen, som återigen berättar om något han varit åsyna vittne till: fältmarskalk Klingspors ankomst till prostgården. Denna bild av intervjusituationen i miniatyr ger en ökad närhet till det berättade genom citaten i direkt anföring, som får oss att känna att vi får höra samtalet precis som det utspann sig, även om detta sannolikt är en illusion (jfr Genette 1983, 172-173).För att anknyta till Katharine Galloway Youngs välkända modell för analytisk indelning av berättarsituationens dimensioner, har konversationens sfär (the realm of conversation) dragits in i berättelsevärlden (taleworld) (Young 1987). Därtill styrker hänvisningen till berättarsituationen den primäre berättarens anspråk på rätten att berätta: han var där och lyssnade till vad sagesmannen hade att säga.

Beträffande den kronologiska ordningen i detta avsnitt av berättelsen, tar denna avstamp i tiden för intervjuerna med sagesmännen. Den med dalkarlens son ägde rum 1876. Det förekommer sedan ett hopp fram i tiden (en proleps) till 1878, då Wefvar tycks ha fătt upplysning om att sagesmannen ännu levde. Därefter rör sig berättelsen i en tillbakablick (en analeps) till 1808, först till ett par dagar före slaget, då kosackerna började dyka upp, och sedan till dagen före slaget, när Klingspor gästade prostgården. Här förflyttar vi oss för ett kort ögonblick i en proleps till 1876, för att slutligen återgå till 1808 och dagen före slaget. Berättelsen fortsätter sedan sålunda:

\footnotetext{
Den 13 september kom den svenska armén till Vörå. Helsingländingar och andre svenska soldater, när de hörde ortens dialekt talas, föreföll det, som de hade varit i sitt hemland. [3] Redan i Bergby och Kåske, de sydvestligaste byar $i$ Vörå visade sig Kosackerne för närgångne, och en fäktning mellan dem och svenska dragoner var nära att utbryta. De redo omkring skjylarne $i$ en rågåker, undet det de från hvardera hället försökte att parera hvarandras anfall och sabelhugg. Slutligen drogo sig Kosackerne utan någon nämnvärd skada till den ryska förtruppen och dragonerne redo till den svenska armén. Omkring kl. 5 e.m. tågade den svenska hären förbi den nordligaste by, Karfvat i Vörå. Numera hör Karfvat till Oravaiskommun. [4] Enligt häradsdomar Bengt Lassus' (död 1875) berättelse derom, följde Kosackerne Svenskarne i hälarne. "Ja", berättade han derom, "var me fár menn, to an tjöd $i$ rian om dájin o sat po langflakan, so ja sua to Svenskan kom. Kasakkan va nére báket. To Svenskan kom en beta in på skoujin, stakk se en houp soldáter me vejin, so int Ryssan sua dem. To Kasakkan sedan kom sköut dem puå dem. Kasakkan ruåka millan tvuå eldar o motta fäll pik o jev se. He fi dem to fy nésvisheiten sin." [Jag ... var med min far, då han körde till rian om dagen och satt på långflaken, så jag såg då svenskarna kom. Kosackerna var nere bakefter. Då svenskarna kom en bit in på skogen, stack sig en hop soldater vid vägen, så att kosackerna inte såg dem. Då kosackerna sedan kom sköt de på dem. Kosackerna råkade mellan två eldar och måste fälla pik och ge sig. Det fick de då för sin näsvishet.] Svenskarne tågade ofver [sic] den mer än en half mil långa Karfvatskogen och kommo till Fjäl (Fjärd)backen, en halffärdingsväg söder om Oravaiskyrkan. Söder om denne backe ligger den s.k. Fjälsängen genomfluten af Fjälsbäcken, som rinner ut $i$ Oravaisfjärden. Denne bäck torkar ut under torra somrar. Detta var äfven fallet sommaren 1808. Redan
} 
Camilla Asplund Ingemark: En upptecknare berättar

\begin{abstract}
tidigt på morgonen den 14 september hade en hel hop ryska soldater smugit sig till samma bäck, vid hvilkens höga stränder de funno skydd mot Svenskarnes kulor. Redan kl. 6 f.m. var Kulneff $i$ farten med sin trupp. [5] På Fjälsbacken hade Svenskarne sina batterier och kanoner. Nära dessa var en stor jordfast sten. Bakom denne sten smög sig en bonde Anders Pensala frän en by med samma namn i nämnde socken. Pensala hade krupit bakom denne sten, för att han "sku få skod, to dem kriar" [skulle få se, då de krigar]. En minnesbeta fick han dock frän samma sten. Redan på förmiddagen träffar en rysk kanonkula samma sten med en sådan styrka och dån, att Pensala deraf blef lomhörd för sin återstående tid. En annan kanonkula träffar ännu längre fram på dagen den samma stenen med en sådan stöt, att bara skärfvorna flögo derifrån, och några till och med sårade litet den nyfikne mannen $i$ ansigtet. Han ryckte då till, men stannade ändock quar till eftermiddagen. "Se på bonden!" tyckte artilleristerne vid närmaste kanon, när de sågo honom springa upp, då han blef träffad af stenskärfvorna från stenen efter en kanonkula. [6] Här på Fjälsbacken träffades äfven en soldat Kyrkbom af en kula $i$ benet och bars sedan sårad till närmaste bondgård, der han blef förbunden. En annan soldat àter förlorade sin tumme. Han började då ropa och gråta samt jämra sig öfver förlusten af sin tumme. "Var tyst nu och skräm icke du bort de andre, nog fär du en annan tumme i stället", sade då den närmaste officer till honom. Han lugnade sig då. [7] Äfven män från Oravais by samt till och med frän masugnen infunno sig till krigsplatsen. At en del sade officerarne: hva gör ni här, tills någon kula träffar er, inte skulle vi heller vara här, om vi icke måste." En och annan sårade [sic] försökte äfven desse män hjelpa hvad de kunde.
\end{abstract}

(SLS 102, 273-275)

Detta avsnitt är länkat till det föregående genom en tidsdisposition, eftersom Klingspors ankomst till prostgården och den svenska arméns till Vörå infaller på samma dag. Kronologin är sannolikt mer eller mindre samtidig. Därefter återknyter berättaren till orten, i detta fall via dess dialekt. Sedan inleds delberättelsen om dragonernas och kosackernas skärmytsling i rågåkern. Hela detta parti berättas utan hänvisning till någon sagesman, varför den primäre berättaren rimligtvis bör betraktas som den som för ordet. Han är återigen en extradiegetisk-heterodiegetisk berättare. Övergången till nästa delberättelse sker genom en dubbelbindning, via såväl tiden som rummet, där förflyttningen i båda dimensionerna är viktig. Kommentaren "Numera hör Karfvat till Oravaiskommun" är antagligen ett uttryck för den primäre berättarens berättande, då ett förtydligande av denna förändring i administrativ tillhörighet kanske inte hade föresvävat den ursprunglige berättaren.

Nästa delberättelse har en namngiven sagesman, som Wefvar råkat ge fel förnamn. I SLS 275 har han dock angett det korrekta namnet, M[årten] Lassus (SLS 275, 94), som annars är mest känd för sina anteckningar om sägner från Vörå. Dessa finns som maskinskriven kopia i Svenska litteratursällskapets samlingar (SLS 299). $\mathrm{Nu}$ överlämnar den primäre berättaren gradvis ordet åt Lassus, som blir en metadiegetisk berättare, en berättare som framför en berättelse inuti ramberättelsen. Efter Lassus' värdering av sin berättelse, att kosackerna förtjänade att bli nedskjutna för sin näsvishets skull, återtar den primäre berättaren ordet. Bryggan till nästa delberättelse utgörs av en förflyttning i rummet, svenskarnas marsch över Karvatskogen 
till Fjärdsbacken, varför det handlar om en rumsdisposition. Denna brygga är en del av en längre bakgrundsorientering, som utmynnar i berättelsen om Anders Pensala. Länken mellan bakgrundsorienteringen och berättelsen om Pensala är också rumslig: den sten han krupit bakom ligger nära svenskarnas batterier och kanoner på Fjärdsbacken. Denna delberättelse komplicerar kronologin i ramberättelsen. I bakgrundsorienteringen sägs att slaget började klockan 6 på morgonen, och längre än så har ramberättelsen inte kommit. Berättelsen om Anders Pensala sträcker sig dock ända in på eftermiddagen, så att den utgör en framåtblick (proleps) i förhållande till ramberättelsen.

Efter detta följer en rad korta omnämnanden av personer som blivit sårade, vilket bildar en tematisk brygga mellan dessa och berättelsen om Pensala. Som temadisposition är den utpräglat additiv, nästan som en lista. Det sista partiet om andra personer som närvarade vid slaget återknyter också tematiskt till berättelsen om Pensala, men ur en annan synvinkel. Berättelsen fortsätter:

\footnotetext{
Ett häftigt bajonettanfall gjorde Svenskarne på f.m. på Ryssarne på Fjälsängen och fördrefvo dem till den motsatta backen på andra sidan om Fjälsbäcken, der Ryssarne nu fattade posto och gjorde med fullt allvar motstaind, sedan de af Svenskarne fördrifvits bort frain Fjälsbäcken och ängen. Här stupade ofantligt mycket folk. På berg, vid stenar, buskar och träd hade Ryssarne sökt skydd och med laddade gevär voro de beredde att emottaga de anfallande Svenskarne. Desse studsade litet tillbaka; men de ordnade sig snart till ett nytt anfall. En svår strid uppstod nu. Ryssarne drogo sig ännu längre söderut åt det s.k. Lillträsket. En och annan enskild händelse hörde man ännu på 1870 och 1880 [sic] af äldre personer omtas [rättat till: omtalas] från detta fältslag. [8] Bland annat berättas det: höll en soldat frän Närpes, af finsk börd, och en Rysse "heila dajin o sköut po hvarader utan ti träffa [hela dagen och sköt på varandra utan att träffa]. Slutligen lade sig den finske soldaten som hette Smidts [sic] ner på marken för att sålunda kunna framlocka sin fiende. När nu ryssen hade affyrat sitt gevär, träder han fram frän trädet för att se, om hans fiende verkligen ännu lefde. "To mokka ja an i prysti" [Då slog jag honom i bröstet], tyckte Smidt, och Ryssen föll till marken, träffad af hans kula. [9] En rysse och en svensk hade fallit för hvarandras vapen så nära hvarandra, att de blott lågo med hufvudet åt olika håll. [10] Två svenska soldater följdes àt större delen af dagen. Men då kommer en Rysse fram ur skogen och skjuter den ene af desse kamrater. Den andre började genast jaga efter sin fiende, tills han fick sigte på honom och sköt honom. [11] En svensk häller fram sin mössa och en Rysse skjuter derpä, emedan han antog att den skulle vara hufvudet af en soldat. Så gjorde han gång på gång, tills den ryske soldaten bortskjutit alla sina patroner. Nu rusar svensken fram och fäller sin fiende. [12] Vid quarnen invid Lillträsket stadnade soldat Strang, ställer sitt gevär vid qvarnväggen och aflàter sitt vatten, men med detsamma blef han fängad af några ryska soldater, hvilka skynda fram ur skogen. [13] Redan på morgonen samma minnesvärda dag skulle en drucken man från Kimo gå till Karfvat by $i$ Vörå för att slagta. När han kom till Fjälsbacken, varnade svenska soldater honom och sade: "far du till Karfvat der ett annat slagtande i dag kommer att blifva, sä är du olycklig. Men bonden var envis och lät icke säga sig, utan gick. Han lyckades ock hinna bra nära Karfvat by, då han blefgripen av Ryssarne.
} 
Camilla Asplund Ingemark: En upptecknare berättar

\begin{abstract}
Han fick nu hela dagen maka om eldbränder och den följande natten måste han ock sköta om Ryssarnes vakteldar. Sedan då slaget var slut och Ryssarne tågade norrut, släppte de bort honom. Han behöfde icke mera tänka på något slagtande för denne dag. En väldig slaktning på folk hade nu försiggått och öfver 2000 menniskor lågo döda eller sårade "i Karvatskóujin" [i Karvatskogen]. Alla nöt de ryska soldaterne dagen före slaget öfverkommit, blefvo äfven slagtade och uppätna af Ryssarne. Närmaste stuga till landsvägen vid vägaskälet, der byvägen går till Karvat, kallas "Hagabacka". Förr var denna stuga ensam derstädes. Inom loppet af 12 àr háfva 3 andra stugor tillkommit. I lindan invid denna stuga blefvo 50 ryska och en svensk soldat begrafne vid samma fältslag. [14] Kl. 2 à 3 e m kommo ryska artillerister med 3 ryska kanoner och foro med dem söderut. Gintemot Vörå kyrka stadnade de med sina kanoner, då de efter ett par timmars hvila derstädes vände om och foro tillbaka till Oravais. Det synes vid sakens närmare betraktande, som Kamenski tviflat om slagets utgång, huruvida han skulle vinna slaget och kunna fördrifva Svenskarne frän Fjärdsbacken. [15] Samma dag skulle äfven en bonde från Bodbacka fara till Wasa. På stadsvägen blef han gripen af Ryssarne och ford till General Kamenski. Utaf Bodbacka ville Kamenski hafva upplysning, om någon väg gick från Vörå till Kimoby i Oravais. "Ingan väg gár från Vörå til Kimo. He je oumöjlit ti kom ti me en krígshér [Ingen väg går från Vörå till Kimo. Det är omöjligt att komma dit med en krigshär] svarade bonden. Efter 2 timmar àter blef Bodbacka åter förd till den ryska geniralen, som åter framstälde till honom samma fråga och äfven bekom samma svar, som förra gången. Kamenski släppte nu bort Bodbacka, som fick resa hem. Denne man hade blott ett öga och kallades derför vanligen till "Boubaka einöga Matt" [Bobacka enöga Matt]. Efteråt skall han hafva sagt: "Nou sku ja änto ha veta uå ein vég, tér an ha möjligen kuna stjlipp me foutfolk, men ja vild int fuöruåd Svenskan o teför sa ja int." [Nog skulle jag ändå ha vetat av en väg, där han möjligen kunnat slippa med fotfolk, men jag ville inte förråda svenskarna och därför sade jag inte.]

(SLS 102, 275-277)
\end{abstract}

Detta avsnitt länkar till det föregående genom en tidsdisposition, då ramberättelsen här når fram till förmiddagen. Den primäre berättarens relativt omfattande bakgrundsorientering om slagets gång i detta skede medför även en rumslig förflyttning till Fjärdsbäcken och Lillträsket, och banar väg för ett antal delberättelser, varav vissa inte är mycket mer än referat. Dessa delberättelsers anknytning till bakgrundsorienteringen är tematisk: de exemplifierar de svåra strider berättaren talar om, med fokus på soldaternas öden. Anknytningen är också additiv, eftersom den radar upp berättelserna efter varandra såsom i en uppräkning. Den första delberättelsen, om soldat Smidt och hans ryske fiende, är berättad av den primäre berättaren, men innehåller citat från en anonym sagesman. Den primäre berättaren har alltså åter tillvällt sig en annan berättares berättelse, men låtit denne komma till tals i citatet. Båda dessa berättare är extradiegetiska-heterodiegetiska. Beträffande den kronologiska ordningen avviker denna delberättelses från ramberättelsens, eftersom den sträcker sig över hela dagen, och den är därmed en proleps. Om den även börjar tidigare än förmiddagen är den istället en så kallad blandad analeps, som börjar tidigare och slutar senare än ramberättelsen (Genette 1983, 49).

Den därpå följande utsagan om den ryske och svenske soldaten som stupade nära 
varandra anknyter till berättelsen om Smidt via temat, ryssen och svensken som stod mot varandra. Nästa delberättelse varierar detta med två svenskar som möter ryssen, varvid den ene stupar och den andre hämnas hans död. Delberättelsen om soldaten som lurar ryssen att skjuta bort alla sina patroner förenas i sin tur genom sin betoning på list främst med berättelsen om Smidt. Kronologin är oklar i alla dessa delberättelser, varför det är svårt att uttala sig om hur de förhåller sig till ramberättelsens.

Berättelsen om soldat Strang och hans tillfångatagande introducerar en ny variation på temat soldaternas öden, samtidigt som den utgör en rumslig koppling till bakgrundsorienteringen genom scenen för händelsen, kvarnen vid Lillträsket. Också här förblir kronologin oklar. Så är dock inte fallet med nästa delberättelse om den druckne mannen som skulle bege sig till Karvat för att slakta. Denna berättelse tar sin början redan på morgonen, och berättelsen rör sig sålunda bakåt i tiden för att sedan röra sig framåt igen och nå sitt slut på natten (blandad analeps). Delberättelsen avslutas med den primäre berättarens värdering: slaget hade varit en "väldig slaktning på folk". En liten reminiscens av sagesmannens berättelse återfinns i det dialektala "i Karvatskóujin". Temat slaktning återkommer ännu en gång i konstaterandet att ryssarna nu slaktade all nötboskap de fått tag på dagen innan, vilket innebär att kronologin dröjer kvar vid kvällen och natten efter slaget. Utsagan om soldaternas gravplats är implicit förknippad med temat slaktning, men bygger också på en förflyttning i rummet till vägskälet mot Karvat. Den primäre berättarens kommentar att den omnämnda stugan under de senaste tolv åren fått sällskap av nya stugor förflyttar för ett ögonblick berättelsen till hans nutid (proleps), för att sedan återgå till tiden för slaget.

Därefter går ramberättelsen bakåt i tiden (analeps) till eftermiddagen, i delberättelsen om den ryska truppen som begav sig till Vörå med sina kanoner för att vila. Anknytningen till de föregående delberättelserna bygger på en rumsdisposition, eftersom förflyttningen från Oravais till Vörå och tillbaka igen är huvudsaken. Sedan introducerar den primäre berättaren den ryske befälhavaren, Kamenski, genom sin reflektion att han sannolikt tvivlade på slagets utgång, och berättar därpå historien om Bodbacka Matts möte med Kamenski. Denna delberättelse är kanske närmast förknippad med den om den druckne mannen via en temadisposition, där män som blivit gripna av ryssarna medan de var på resa utgör det gemensamma temat. Den primäre berättaren överlåter ordet åt Bodbacka i ett par citat på dialekt, men det är inte tillräckligt mycket för att man skall kunna säga att Bodbacka blir en metadiegetisk-autodiegetisk berättare. Därpå följande avsnitt av berättelsen lyder:

\footnotetext{
På eftermiddagen kom ryska reserven Ryssarne till hjelp. De intogo sin middag omkring kl. 3 e $m$ i Tuckor, Kovik och Kajtsor byar. [16] Folket hade lämnat sina hus i Tuckor, utom en gammal veteran, Anders Sabel, som varit i krig med Ryssarne redan 1788. Han var hemma. "nou je ja ván ti drás me Rýssan, ja ä int rädd tem" [nog är jag van att dras med ryssarna, jag är inte rädd för dem], tyckte den gamle veteranen och var hemma. Ryssarne benämnde honom blott "starik" och gamle soldat, gaf honom mat och lät honom vara $i$ fred. Oaktadt tre man gingo i bredd, räckte det för den ryska reserven en god half
} 


\section{Camilla Asplund Ingemark: En upptecknare berättar}

timme att tåga förbi Karfvat by. Det var reserven som mot aftonen af dagen ryckte segern ur Svenskarnes händer. De voro nu trötte och hade bortskjutit sin ammunition. De måste draga sig tillbaka. I mörkret och oredan blefvo en del av den svenska hären och de soldater, som voro längst àt vester trängda àt "yttersta laddjin" [yttersta udden] af Oravaisfjärden, der något 100 man blefvo tillfängnetagne. En del af desse olycklige soldater summo och vadade öfver nämnde fjärd till den motsatta Fjälsbacken. Några påstå, att det var blott en af desse, som vågade detta lifsfarliga försök. [17] En del af Svenskarne vid återtåget blefvo vid sjöstranden kringrände af Ryssarne. I denna trupp befunno sig äfven åtskilliga svenska bönder. Soldaterne angrepo nu Ryssarne och slogo sig igenom. "Huru gick det med eder, när i måsten laga er undan Ryssarne?" frägade folket af dem, när de sedan om aftonen kommo hem. "Visst hörde vi gevären skramla", svarade de, när den trupp, der desse bönder voro, slog sig igenom sina fiender och banade med bajonetten sig väg fram till landsvägen." [sic] En af de soldater, som voro med $i$ detta slag var Karl Johan Svahn, eller som han efter krigets slut kallade sig Karl Johan Sjölund. [I fotnot: "Denne åldrige veteran frän Snappertuna träffade jag i Aug. 1877. Gubben gick rak och utan käpp, var ute på åkern och hjelpte till med skördarbetet. Han dog vid 93 àrs [sic] den 3 mars 1878. Redan 1804 var han stadd $i$ svensk militärtjenst som soldat vid Abborfors. "Från Tornå [sic] fikk vi vänd tibàk" [Från Torneå fick vi vända tillbaka], sade han. Om slaget vid Oravais tyckte han: "vi bihöld rejdan plassen" [vi behöll redan platsen]. Redan 1807 var han soldat vid Abborfors.] [18] Vid rågrinden på Oravaisskogen vände baron Stromberg, kapten för Vöråkompaniet, om. Det var nu e.m. och ryska reserven trängde allt häftigare fram. Stromberg med sina Vörågossar var bland de första $i$ den finska hären, som med bajonett gjorde ett anfall på ryssarne för att få dem bort från Fjälsbäcken och Fjälsängen. Vesterbottningar [sic] Helsingländingar, Österbottningar, Nyländingar, icke blott Svenskar utan äfven Finnar hade redan i timmar på Fjälsängen stridt med Ryssarne och utgången af fältslaget var oviss. Blod hade äfven betydligt flutit, och ingen utsigt till seger fanns ännu för Svenskarne. Då beslöto Svenskarne att med ett bajonettanfall fördrifva sina fiender frän den motsatta eller södra sidan af berörda äng. Här i skogsbrynet samt på ängen voro väldiga massor af ryska soldater posterade. Svenskarne hade litet värn af ängsladorna. När Vöråkompaniet skulle uppbryta, säger trumslagarn àt Stromberg: "baron làter nedskjuta sitt folk här. Här stupar den ene efter den andre." "Ja illa går det. Jag tror just, att vi slä: fäll bajonett." [sic] svarade Stromberg. Det behöfdes intet sägas två gånger, förrän hela kompaniet likasom hela den svenska hären stormar mot Ryssarne, som hastigt drogo sig bort frän ängen och flydde upp àt skogen. Här gjorde de ett häftigt motstånd; men de blefvo det oaktadt trängde längre àt Vörä, tills de på eftermiddagen fingo hjelp af reserven. [19] Krut och ammunition började längre fram på dagen tryta Svenskarne. De skickade bud derom till fältmarskalken och begärde mera såväl krut som kulor. Klingspår försänder dem då en ammunitionskista. När man kom fram med henne till stridsplatsen och öppnar henne, var hon tom. De svenska soldaterne plockade sedan upp kulor och de patroner de hittade på marken på landsvägen och på ängen vid Fjälsbäcken samt frän de ställen $i$ skogen hvarest striden föreföll som hetast. [20] När en soldat Lager vid återtåget till Fjälsbacken kom att gå öfver Fjälsängen, såg han, huru hans hustru hade höbergat hans äng, men dåligt igenlagat ladudörren. "Det här duger intet, dörrar skall ordentligt åter, om icke regn skall förderfva höet, eller boskapen uppäta hälften af det inbergade förrådet. " [sic] tyckte han och lagade dörren så väl åter som 
Camilla Asplund Ingemark: En upptecknare berättar

\begin{abstract}
tiden och brådskan medgaf det. Sedan lade han geväret på axlen och skyndade i väg. När han kom ut åt ofvanberörde Fjälsbäcken hörde han i skymningen, huru en rysk trumslagare kommer till sidan af bäcken och började väldeligen dundra och slå på sin trumma. "Ja ska lär de trumb" [Jag skall lära dig trumma], tänkte Lager och sökte på marken efter någon patron för att få sitt gevär laddadt. Slutligen hittade han på en karteschpatron. Som han hade laddat med denne karteschpatron och afskjutit skottet, tystnade ryssens trumma. Om skottet sedan träffade sjelfva trumslagaren eller skadade hans trumma, så att hon icke mera gaf något ljud ifrån sig, visste inte Lager med säkerhet. [21] Andre som berättat samma sak, säga, att det icke var Lagers skott, som träffade den ryske trumslagaren, utan soldat Smidts. Smidt var finne men soldat i Närpes. När han hade laddat sitt gevär och affyrat skottet säger han på bruten svenska: "ja ska ke de." [jag skall ge dig] Med det samma tystnade trumman, så att hans karteschskott måste då hafva träffat antingen den ryske trumslagaren sjelf eller förderfvat hans trumma. Efter krigets slut blef Lager väktare i Oravais kyrka. [22] Smidt blef under slaget på något sätt under stridens lopp skild från sin kamrat och trodde, att han hade stupat. Sedan under mönstringen i NyKarleby, så träffade de båda kamraterna hvarandra i lifvet. De voro då så glade, att de ännu sågo hvarandra i lifvet, att de såsom Smidt berättade ("vi krét") greto af glädje. Svenskarne drogo sig nu norr ut till Ny Karleby.

(SLS 102, 278-280)
\end{abstract}

Ramberättelsen uppehåller sig ännu vid eftermiddagen, och nu anländer den ryska reserven, som visade sig så avgörande för slagets utgång. Vörå utgör fortfarande scenen för berättelsen, vilket framgår av den primäre berättarens bakgrundsorientering till den första delberättelsen om Anders Sabel, den gamle veteranen från närmast föregående krig med Ryssland, Gustav III:s ryska krig 1788-1790. Kopplingen till föregående avsnitt sker alltså på såväl ett tidsmässigt som ett rumsligt plan, men det finns också inslag av en orsaksdisposition, eftersom det är just den ryska reservens ankomst till Tuckor som föranleder alla invånare, utom veteranen, att fly från sina stugor. Den primäre berättaren återvänder sedan till reservens marsch för att meddela hur länge det tog den att tåga förbi Karvat. Förbindelsen mellan delberättelsen om Sabel och den efterföljande bakgrundsorienteringen bygger därmed på en rumsdisposition, med en förflyttning från Tuckor till Karvat. Bakgrundsorienteringen rör sig sedan vidare till den yttersta udden av Oravaisfärden, fortsätter till Fjärdsbacken mittemot för att slutligen återvända till sjöstranden i delberättelsen om de kringrända svenskarna. Här låter den primäre berättaren tillfälligt karaktärerna komma till tals i en kort dialog, men eftersom den återges på högsvenska istället för på dialekt framstår den snarare som framsprungen ur hans mun än ur Vöråbönders.

Ramberättelsen har nu kommit fram till kvällen. I den inskjutna kommentaren om Karl Johan Svahn och hans namnbyte flyttas vi i en proleps framåt i tiden till efter kriget, för att sedan återgå till stridsdagens eftermiddag (analeps) i delberättelsen om baron Stromberg och vöråkompaniets bajonettanfall. Den primäre berättarens bakgrundsorientering betonar de svenska och finska soldaternas mödosamma ansträngningar att fördriva ryssarna från Fjärdsängen, som här blir scen för berättelsen, och slagets blodighet och ovissa utgång i detta skede. Händelsen i denna delbe- 
rättelse initieras av Strombergs och hans trumslagares ordväxling, som återges på högsvenska. Den primäre berättaren behåller återigen ordet, men tillåter sig att citera karaktärerna.

Som ett resultat av de hårda strider som beskrivits, tar svenskarnas ammunition slut. Kopplingen mellan delberättelsen om Strombergs kompani och den tomma ammunitionskistan bygger sålunda på en orsaksdisposition. Länken mellan denna referatlika delberättelse och den om soldat Lagers tystande av den ryske trumslagaren har i sin tur ett gemensamt tema - bristen på ammunition - som grund. Här röjer den primäre berättaren att hans berättelse egentligen är någon annans, eftersom han hänvisar till "[a]ndre som berättat samma sak". Att det förhåller sig så är naturligtvis något som är underförstått $\mathrm{i}$ hela berättelsen: den utger sig ju trots allt för att vara en folkloristisk uppteckning, gjord efter sagesmännens berättelser. Det är ändå påtagligt att den primäre berättaren så sällan nämner sina sagesmän vid namn, eller ens låter påskina att de existerar.

De andra som berättat om samma sak säger att det istället var en annan person, soldat Smidt som vi mött i en tidigare delberättelse, som sköt den ryske trumslagaren. Såsom en variant av samma delberättelse sammanfogas den med berättelsen om Lager genom en additiv tematisk disposition. De båda varianterna av delberättelsen utspelar sig i skymningen i samband med reträtten norrut. I den primäre berättarens kommentar om att Lager blev kyrkoväktare i Oravais efter kriget, hoppar vi framåt i tiden (proleps), för att sedan backa till en oklar tidpunkt "under stridens lopp" i den sista delberättelsen i detta avsnitt, då Lager och Smidt, som är bästa vänner, kommer ifrån varandra och tror att den andre har stupat. Därefter förflyttar vi oss framåt i tiden till mönstringen i Nykarleby (proleps), då kamraterna upptäcker att båda överlevt, för att sedan återgå till tiden för reträtten till Nykarleby. Berättelsen fortsätter:

\footnotetext{
På Bertills i Oravaisby hade Svenskarne sitt lasarett. Vid Ruona brände ryssarne upp sitt eget lasarett, som en gammal soldat, som deltagit i slaget derstädes och ännu lefvde på 1870talet, visste berätta. Med lasarett Svenskarnes [sic] på Bertills hemman gjorde de på samma sätt, då desse ej hunno eller kunde på sin ambulans föra alla de sjuka och sårade med sig. [23] En Vesterbottnisk soldat, som var på samma lasarett och var sårad i ansigtet, då kulan farit in vid den ena sidan af munnen och ut genom den andra, lagade sig ut ur stugan, när han såg, hvad ryssarne ämnade göra derstädes och gömde sig $i$ en buske på gården. En rysk soldat kastade sitt vatten på honom, men kunde icke i mörkret se honom. Längre fram på quällen förfogade han sig till Pensala by i Munsala, och derifrån till $N y$ Karleby. [24] I Pensala höllo bönderne sjelfve patrull $i$ byn under natten. De kastade stenarne $i$ väggarne och väsnades förfärligt. Kosackerne som under rekognoscering ämnade besöka byn, blefvo rädde, när de hörde ett sådant buller, och trodde att det var svenska soldater, ropade àt hvarandra "Svitski" och redo bort. [25] På samma sätt gick det med Kosackerne i Jeppo. Kosacker och ryska soldater togo der efter kor och slagtnöt. Nära Romarby hade de ock lyckats fä en mindre hjord af kor, som de drefvo att simma öfver ån till den motsatta stranden. Vid samma tillfälle voro bönder druckne och väsnades och förde ett förfärligt oljud. De kommo öfver ängar och hagar och gingo ut àt landsvägen. Desse män
} 
Camilla Asplund Ingemark: En upptecknare berättar

\begin{abstract}
voro "Runttolfman" (nämndeman Runt och "Paksu Matt") bonden Matts Paksu. När Kosackerne hörde deras hojtande skrikande och ropande, trodde de att det var svenska soldater, och ropade förskräckt: "Svitski" och redo bort. Korna åter summo då då [sic] tillbaka öfver an och foro till skogen.

(SLS 102, 281)
\end{abstract}

I den första delberättelsen i detta avsnitt återvänder vi till Oravais och Bertills hemman i kyrkobyn, där svenskarna hade sitt lasarett. Dispositionen är sålunda en rumsdisposition. Efter att denna scen för berättelsen introducerats, förflyttas vi för ett ögonblick till Ruona, där en strid ägde rum den 31 augusti 1808. Här sägs ryssarna ha bränt upp sitt eget lasarett. I samband med att den primäre berättaren hänvisar till sin sagesman, en gammal soldat som deltog i nämnda slag, rör vi oss tillfälligt framåt i tiden till 1869 (proleps), då berättaren talade med honom. I SLS 275 nämns han vid namn, Borgar i Karvat, och det är också i detta sammanhang vi får veta när han intervjuades (SLS 275, 114). Därefter återgår berättaren till lasarettet på Bertills, som också blev nedbränt, och kvällen den 14 september 1808. Sedan den västerbottniske soldaten räddat sig ur den brinnande stugan, beger han sig så småningom till Pensala i Munsala och därifrån till Nykarleby.

Nästa delberättelse utspelar sig i Pensala, varvid den primäre berättaren återvänder dit genom en rumsdisposition. Delberättelsen utspelar sig på natten, då bönderna väsnas för att hålla ryssarna borta. Denna delberättelse länkas till den följande via en temadisposition, eftersom samma sak sägs ha hänt i Romar by i Jeppo. Den primäre berättaren gör här åter en förflyttning i rummet, medan tiden sannolikt är ungefär den samma. Övergången mellan de båda delberättelserna, "På samma sätt gick det med Kosackerne i Jeppo", är ett tydligt exempel på hur den primäre berättaren håller samman ramberättelsen genom sina kommentarer. Det sista avsnittet av berättelsen lyder:

\footnotetext{
Den delen af Oravaisbyn som sträcker sig från kyrkbacken ut àt Bertills och Kulla, kallas "Leiruna". [26] När svenska hären tågade der fram samma dag slaget stätt, var eftertruppen betäckt med en välladdad kanon. Kosacker följde efter, och af deras rörelser, så syntes det som hade de for afsigt att fräntaga Svenskarne denne kanon. Den svenska artilleristen, som bevakade kanonen, förstod att skickligt forra ryssarne bakom ljuset. Han svängde luntan, som ämnade han affyra kanonen, när ryssarne kommo nära: men han gjorde det icke. Kosackerne drogo sig då tillbaka i den förmodan, att han skulle skjuta. Men när han ej gjorde det, kommo de àter närmare, så att man tydligen kunde se, att de ämnade beröfva svenska eftertruppen detta fältstycke. När nu artilleristen ej affyrade det, tänkte Kosackerne att han inte hade sin kanon laddad och skulle verkligen bestorma och borttaga den. Men med detsamma sänkte den svenska artilleristen luntan och $i$ ett ögonblick låg vägen full med döde och sårade ryska soldater och Kosacker. [27] Redan på morgondelen af samma märkvärdiga dag blefvo 3 ryska soldater fängne och instängde $i$ en badstuga $i$ byn, der man torkade hampfrö. Under dagens lopp àto de hungriga och utsvultne soldaterne upp hela detta förraid af hampfrö, och de hade ännu dertill fätt blifva qvar i samma badstuga, om icke deras
} 
Camilla Asplund Ingemark: En upptecknare berättar

\begin{abstract}
kamrater om aftonen af ljudet hade hört, att de voro ryssar samt kommit och släft ut dem. För den ryska öfvermakten måste Svenskarne draga sig norrut. Alla som helst litet kände till detta slag, sade, att Svenskar slogos som hjeltar, men måste då soldaterne bortskjutit sitt krut och sina kulor draga sig undan norrut. I Lassusbacken öster om Oravaiskyrkan hade äfven Svenskarne en kanon. Blott en qvinna af dem som anfört något om slaget i Oravais skog sade, då hon för mig berättade hvad hon visste derom: "Kamenski hade sagt: "fär jag Svenskarne bort frän Fjälsbacken, behåller jag platsen."
\end{abstract}

(SLS 102, 282-283)

Detta avsnitt sammanlänkas med det föregående via en rumsdisposition: vi återvänder från Jeppo till Oravais. I den första delberättelsen förflyttas vi till "Leiruna", området mellan kyrkbacken och Bertills samt Kulla hemman. Det är fortfarande kväll, eftersom berättelsen utspelar sig under reträtten norrut. Temat, kosacker som blir lurade, bidrar till att förena denna delberättelse med de föregående, som kan sägas bygga på samma tema.

Nästa delberättelse har en liknande tematik som grund, ryska soldater som råkar illa ut. Här tar berättelsen sin början redan på morgonen (analeps), då soldaterna blir inlåsta i bastun, och slutar på kvällen när de blir utsläppta av sina kamrater. Den primäre berättarens värdering av slaget framkommer i uttrycket "samma märkvärdiga dag". Han betecknar också den ryska armén som en "öfvermakt", som tvingade svenskarna att dra sig norrut. Än en gång berör han reträtten, som uppenbarligen är av vikt för honom, eftersom han återkommer till den så ofta. Detta är ett utslag av vad Gérard Genette kallar frekvens, hur många gånger någonting omtalas, i detta fall en enstaka händelse som omnämns flera gånger (Genette 1983, 113-116). Förutom i de delar av ramberättelsen som skildrar reträtten, omtalas den ett antal gånger i andra sammanhang. Här visar den sig utgöra en brygga till sagesmännens omdömen om svenskarnas stridsinsatser, som berättaren sammanfattar i orden: "Svenskar slogos som hjeltar". Det var omständigheterna, i form av bristen på ammunition, som tvingade dem att retirera. Den primäre berättaren delar rimligtvis denna uppfattning, eftersom den tillskrivs "Alla som helst litet kände till detta slag"; de som var av avvikande åsikt ansågs kanske inte veta vad de talade om. Samtidigt bekräftar den primäre berättaren att sagesmännen finns, och att de har varit många, fastän de sällan syns i hans berättelse.

Därefter återknyter den primäre berättaren tematiskt helt kort till den första delberättelsen i detta avsnitt med att nämna att svenskarna även hade en kanon i Lassusbacken öster om kyrkan. Slutligen för han oss i en proleps fram i tiden till en intervjusituation, där en anonym kvinna ger honom en upplysning han uppfattar som viktig. Varför den är det framgår inte riktigt, men här kommer SLS 275 oss till hjälp. Av motsvarande parti i denna samling, som är värt att återge som jämförelse, ser vi att citatet är lösryckt ur sitt sammanhang i SLS 102: 
Camilla Asplund Ingemark: En upptecknare berättar

\begin{abstract}
[...] För att vinna seger tog Kamenski sin utväg till krigslist, då han fann omöjligheten att kunna kringgå sin fiende. Han drog sig tillbaka åt Vörå med hufvudstyrkan och lade en mindre afdelning i skogen i försåt för Svenskarne. Märkvärdigt är det, att allmogen på orten, som eljest tyckes ha reda på hela fältslagets gång, aldrig vet eller anför något om denna tilldragelse, som gaf striden en annan vändning och fränryckte Svenskarne den redan till bälften vunna segern. Det är blott en enda gång jag hört af en medelälders qvinna yttras hvad Kamenski redan före bataljens början skall hafua sagt i detta syfte: "färjag Svenskarne bort frän Fjälsbacken, så behåller jag platsen."[...]

(SLS 275, 96)
\end{abstract}

Yttrandet syftar sålunda på en krigslist, som fick en avgörande betydelse för slagets utgång. Det utgör en förklaring till nederlaget. I och med detta visar det sig också att kvinnans upplysning syftar tillbaka på tidpunkten för den ryska reservens ankomst och svenskarnas bajonettanfall, varför den utgör en speciell typ av analeps, som Genette benämner paralips (av grekiskans "lämna åt sidan"). Den innebär att berättaren har förbigått ett betydelsefullt element i sin redogörelse för en situation, och att denna information sedan ges i en tillbakablick (Genette 1983, 51-52), såsom här. Paralips är ofta ett sätt att undanhålla läsaren förklaringen till ett skeende tills längre fram i berättelsen, men i detta sammanhang tror jag att avsikten kan ha varit att framhålla upplysningens vikt genom att placera den sist.

\title{
DisKussion
}

Den primäre berättaren använder sig således av ett antal dispositionstyper, ibland i kombination med varandra. Såsom jag observerat ovan, bygger berättelsen i sin helhet på en tidsdisposition. Vid sammanfogningen av delberättelserna överväger däremot temadispositionen, och rumsdispositionen är också vanligt förekommande, medan tidsdisposition och orsaksdisposition är sällsynta. Det är tydligt att det meningssammanhang den tematiska dispositionen skapar samt förankringen i rummet betraktades som nödvändiga för att göra historien meningsfull.

Den kronologiska ordningen i berättelsen är komplex, även om den på ett övergripande plan är rak. Då ramberättelsen tar sin början vid tiden för intervjuerna, innebär det att själva berättelsen om slaget är en lång tillbakablick, en analeps. I övrigt spelar tillbakablickar och framåtblickar i stort sett en lika framträdande roll, i och med att blandad analeps och paralips kan räknas till tillbakablickar. Framåtblickarna har i allmänhet två funktioner. Antingen ger de en upplysning från berättarens samtids horisont, eller så kräver delberättelsen helt enkelt det för att bli fullständig: den förs till sin logiska slutpunkt, som Genette uttrycker det (Genette 1983, 68). Tillbakablickarna fyller samma funktioner, men det finns också enstaka exempel på att de utgör bryggor till ett senare eller tidigare stadium i ramberättelsen.

Berättarrösten å sin sida, som till övervägande del tillhör den primäre berättaren, är i allmänhet extradiegetisk-heterodiegetisk. Det är i början av berättelsen avvikel- 
serna från detta mönster står att finna. Berättarrösten förändras dels i delberättelse 2, där den primäre berättaren steg in i berättelsen som en intradiegetisk berättare, och stod i samspråk med sagesmannen, dels i delberättelse 4 i vilken han successivt överlämnade ordet åt sagesmannen, som uppträder som en metadiegetisk-autodiegetisk berättare. Den primäre berättaren har sålunda en uttalad tendens att tillvälla sig sagesmännens berättelser utan att närmare ange sina källor. Jag tror att Wefvar uppfattade det som sin uppgift att samla in, och kanske också systematisera, den muntliga vittnesbörden om slaget för eftervärlden, och att det var därför han renskrev uppteckningen såsom i huvudsak berättad av en primär berättare. En dominerande primär berättare har större kontroll över berättelsens övergripande struktur, vilket gör den mer helgjuten, än vad som hade varit fallet med ett berättande fördelat på både en primär berättare och olika metadiegetiska berättare.

I denna artikel har jag sålunda försökt visa att ett studium av berättartekniken i ett så kallat kompilat kan vara en fruktbar ingång till ett material som ofta betraktas som problematiskt. De källkritiska problemen vid användningen av dylikt material kvarstår naturligtvis, men de gör det inte olämpligt för en närmare analys, om vi som forskare använder oss av sådana metoder och teorier som kan avlocka det såväl tillförlitliga som intresseväckande resultat. Om vi väljer att betrakta kompilatet som inte bara en forskningshistorisk fadäs, sprungen ur sökandet efter folklorens urform, utan också som ett utslag av genuint berättande, kan vi närma oss dem med samma frågeställningar vi brukar reservera för "äkta” folkloristiskt material: vem berättar vad? Hur berättar man? Varför berättar man som man gör? Jag har föreslagit att begreppen disposition, kronologisk ordning och berättarröst kan hjälpa oss att förstå hur kompilatet har skapats, och vilket syftet med det var.

Det folkloristiska studiet av s.k. problematiska material har ökat sedan Satu Apo introducerade begreppet skrivande berättare (kirjoittava kertoja) för att beteckna självbiografiskt skrivande hos en representant för "folket", Alina Vaittinen (Apo 1980, 189). Kirsti Salmi-Niklander har undersökt handskrivna tidningar som en form av kollektivt skrivande (Salmi-Niklander 1997), medan Tuulikki Kurki har fokuserat på Heikki Meriläinens samlingar av folklore och skönlitterära folklivsskildringar som en intertextuell helhet (bland annat Kurki 2004). Förhållandet mellan det skrivna ordet och muntlig tradition är en gemensam nämnare för många av dessa analyser, och även om detta gestaltar sig annorlunda i mitt material - Wefvar hade inga litterära ambitioner som Meriläinen, och berättade inte om sitt eget liv som Vaittinen finns det vissa beröringspunkter. Kurkis tanke på att Meriläinens skönlitterära texter låter "den andra rösten" komma till tals, en röst som talar om folktraditionen ur ett folkligt perspektiv fast i en skriftlig dräkt, kan appliceras på Wefvar i så måtto att det sannolikt var hans ambition att göra just detta. Han lyfter fram den mångstämmiga folktraditionen, men förenhetligar den samtidigt genom sitt berättargrepp. 
Camilla Asplund Ingemark: En upptecknare berättar

\section{KäLLOR}

\section{Forskningsmaterial}

Svenska litteratursällskapet i Finland, Helsingfors: Folkkultursarkivet SLS 102, SLS 275, SLS 299

\section{Litteratur}

ANDERSSON, OTTO 1967: Finländsk folklore. Tidig kalevalaforskning, finlandssvensk insamlingsverksamhet. Åbo: Åttas förlag.

APO, SATU 1980: Alina Vaittinen, kirjoittava kertoja. Kertojat ja kuulijat. Kalevalaseuran vuosikirja 60. Helsinki: SKS. 185-189.

ASPLUND INGEMARK, CAMILLA 2004: The Genre of Trolls. The Case of a Finland-Swedish Folk Belief Tradition. Åbo: Åbo Akademis förlag.

ASPLUND INGEMARK, CAMILLA \& WASSHOLM, JOHANNA 2009: Historiska sägner om 1808-09 års krig. Skrifter utgivna av Svenska litteratursällskapet i Finland 728. Helsingfors: Svenska litteratursällskapet i Finland.

BERGMAN, ANNE 1981: Nyländska avdelningens och Svenska litteratursällskapets folkloristiska insamlingsverksamhet 1860-1908. Fynd och forskning. Till Ragna Ablbäck 17.7.1981. Skrifter utgivna av Svenska litteratursällskapet i Finland 496. Helsingfors: Svenska litteratursällskapet i Finland. 7-43.

GENETTE, GÉRARD 1983: Narrative Discourse. An Essay in Method. Ithaca \& New York: Cornell University Press.

HELLSPONG, LENNART \& LEDIN, PER 2006: Vägar genom texten. Handbok $i$ brukstextanalys. Lund: Studentlitteratur.

HÅRDSTEDT, MARTIN 2006: Finska kriget 1808-1809. Stockholm: Prisma.

KURKI, TUULIKKI 2004: Tekstit Kansanrunousarkiston liepeillä. Kansanrunousarkisto, lukijat ja tulkinnat. Suomalaisen Kirjallisuuden Seuran Toimituksia 1002. Helsinki: SKS. 65-90.

LABOV, WILLIAM 1972: Language in the Inner City. Studies in the Black English Vernacular. Oxford: Blackwell.

SALMI-NIKLANDER, KIRSTI 1997: “The Enlightener” and “The Whipper”. Handwritten Newspapers and the History of Collective Writing. Elektroloristi 2/97.

SIIKALA, ANNA-LEENA 1990: Interpreting Oral Narrative. Helsinki: Academia Scientiarum Fennica.

WOLF-KNUTS, ULRIKA 1991: Människan och djävulen. En studie kring form, motiv och funktion i folklig tradition. Åbo: Åbo Akademis förlag.

YOUNG, KATHARINE GALLOWAY 1987: Taleworlds and Storyrealms. The Phenomenology of Narrative. Dordrecht: Martinus Nijhoff Publishers.

\section{Camilla Asplund Ingemark är docent i folkloristik vid Åbo Akademi}


Camilla Asplund Ingemark: En upptecknare berättar

\section{AbStraCt}

\section{Camilla Asplund Ingemark: A Folklore Collector Narrates - Narrative} Technique in Jakob Edvard Wefvar's Records on the Battle of Oravais in 1808

The aim of the article is to demonstrate the scholarly interest in a category of archived material that has hitherto been largely denigrated, namely, the compilation. As a combination of originally distinct items of folklore compiled into a narrative whole by a collector, it has been regarded as methodologically both unsound and inauthentic. The author attempts to circumvent this problem by focusing on the collector as a narrator, using an extensive compilation of a famous battle during the Finnish War (1808-09), the Battle of Oravais, as an example. This text belongs among the historical legends concerning this war, some 900 in total, included in the collections of the folklore archives of the Society for Swedish Literature in Finland. In manuscript, it is a ten-page account of the battle constructed by the collector Jakob Edvard Wefvar, one of the great collectors of Swedish folklore in Finland in the late 19th century. The author studies his way of organising the material by examining the synopsis of the text, and his manner of narrating it by analysing temporal order and narrative voice. 